\title{
Formation mechanisms of Fe-Mn concretions in the Vijenac Quarry, Dinaric Ophiolite Zone
}

The Mining-Geology-Petroleum Engineering Bulletin UDC: 552.1

DOI: $10.17794 / \operatorname{rgn} .2018 \cdot 3 \cdot 7$

Original scientific paper

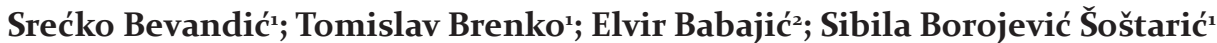 \\ ${ }^{I}$ Faculty of Mining, Geology and Petroleum Engineering, University of Zagreb, Pierottijeva 6, 10000 Zagreb, Croatia \\ ${ }^{2}$ Faculty of Mining, Geology and Civil Engineering, University of Tuzla, Univerzitetska 2, 75000 Tuzla, Bosnia and Herzegovina
}

\begin{abstract}
The Vijenac limestone quarry, near Tuzla in Bosnia and Herzegovina, is composed of carbonate rocks locally embedding tectonically disturbed siltite and sandstone with Fe-Mn concretions. The quarry itself represents a part of Dinaric overstep sequences (the Pogari Formation) unconformably overlying ophiolite mélange and ophiolite trust-scheets. Petrographic, chemical and mineralogical analyses had shown that the concretions may be divided into two types: (i) Mn-rich concretions with $\approx 17 \mathrm{wt} . \%$ of Mn and compact texture and (ii) Mn-poor with $\approx 8 \mathrm{wt} . \%$ of Mn and porous texture. The amount of $\mathrm{Ca}, \mathrm{Fe}$ and $\mathrm{Mg}$ in both concretion types are similar. Nickel and $\mathrm{Cr}$ positively correlate with Fe and $\mathrm{Mn}$, respectively. According to petrographic and mineralogical analyses, concretions are composed of calcite, dolomite, hematite, todorokite and takanelite. Petrographic study confirmed the development of concretions within three stages including two generations of calcite. Studied concretions are formed within consolidated sandstones inheriting their sedimentary textures - therefore a late diagenetic process is assumed.
\end{abstract}

\section{Keywords}

Fe-Mn concretions, diagenetic growth, Mn-minerals, chemical analysis, Dinaric Ophiolite Zone

\section{Introduction}

A concretion is a compact mass of mineral matter, usually spherical or disk-shaped, embedded in a host rock of a different mineralogical composition. Contrary to nodules, concretions show distinct internal structures with concentric zonation (i.e. Gasparatos, 2005). Concretions vary in mineralogical composition, size, shape, hardness, and colour. They are commonly composed of calcite, dolomite, siderite, pyrite, barite, ferromanganese oxides or gypsum. Concretions occur when a considerable amount of cementing material precipitates locally around a nucleus, which is usually some other mineral or fossil remains (Mozley, 2003).

The Fe-Mn concretions and nodules occur in a variety of geological environments like the ocean floor, river sediments, lake sediments, soils and sedimentary rocks. Extensive studies of the ocean floor Fe-Mn nodules have been conducted in order to determine their origin and potential use/exploitation (Bonatti \& Nayudu, 1965; Bender et. al, 1966; Glasby, 1970). Within sedimentary rocks, one of their biggest importance is keeping records of diagenetic and post-depositional changes of the sedimentary units, since they preserve evidence of groundwater flow and the interactions on water-rock boundary

Corresponding author: Sibila Borojević Šoštarić

e-mail address sibila.borojevic-sostaric@oblak.rgn.hr resulting in dissolution and/or precipitation of minerals (Chan et. al, 2007). Concretions have been considered as unusual parts of sedimentary rocks, although they are very often found in sedimentary rocks through different geological periods (e.g., Seilacher, 2001; Mozley, 2003 and references within). Fe-Mn concretions within soils are composed of soil minerals cemented with $\mathrm{Fe}$ and $\mathrm{Mn}$ oxides, oxyhydroxide and hydroxides and their origin is a result of seasonal changes in $\mathrm{pH}$ and redox potential (Eh). The origin of Fe-Mn in concretions is of great interest in environmental geochemistry for their role in metal sequestration (e.g., Gasparatos, 2012; 2013 and references therein).

Within the Dinarides, there are only a few records on the concretions'/nodules' appearances (Chiari et. al, 2013; Lacković, 1998; Photiades, 2010; Posilović et. al, 2016). This study presented the first evidence of the Fe-Mn concretions within sedimentary rocks of the Dinaric Ophiolite Zone (abbr. DOZ), i.e. the Vijenac Quarry, and a unique opportunity to study the corresponding diagenetic and post-depositional changes in sedimentary units. The Vijenac Quarry lies in the area situated between the Neogene basins of Tuzla and Banovići and north-westward of the Krivaja-Konjuh Ophiolite Complex in NE Bosnia and Herzegovina. It is known for its highly pure limestone (up to 97 wt.\% of calcite), with additions of quartz, hematite and fine-grained fraction (Knežević et al., 1986). A border-zone of the quarry is 
composed of siltite and greywacke encompassing numerous brown-black spherical/ellipsoidal concretions.

The aim of this study is to give a better insight into the origin of Fe-Mn concretions hosted by clastic-carbonate sequences of the Vijenac Quarry DOZ, Bosnia and Herzegovina. The presented research contributed to understanding the origin and the syn/post depositional processes within the sedimentary formations associated with DOZ. This article brings results of micropetrography, X-ray powder diffraction (XRD) and atomic absorption spectroscopy (AAS) analyses.

\section{Geological settings}

Vijenac Quarry and the surrounding area is located within the north-western part of the largest ophiolite complex named the Krivaja-Konjuh, situated in the DOZ. DOZ represents the internal unit of the DinarideHellenide Orogenic System, consisting of the following (i.e. Pamić et al., 1998):

a) Mesozoic radiolarite sequences associated with basalts (Pamić, 1982);

b) Ultramafic and mafic blocks featured by metamorphic sole rocks (amphibole and granulite) in their base (Lugović et al. 1991; Pamić, 1997; Šegvić, 2010);

c) Ophiolite mélange composed of a shale-silty matrix in which fragments of greywacke predominate over the ultramafic, mafic and metamorphic rocks, shale, radiolarite, tuff and limestones. In some areas, the mélange displays the distinct olistrome signatures (Pamić, 1982; Dimitrijević \& Dimitrijević, 1973, 1975; Tari, 2002; Šegvić et al., 2014).

d) Late Jurassic / Early Cretaceous overstep sequences (Pogari Formation) transgressive overlying formation b) or c) (Pamić et al, 1998; Hrvatović, 2006). Massive reed limestone of the Vijenac Quarry belongs to this tectonostratigraphic unit.

The geological map (see Figure 1) shows the location of the quarry area within the massive reef limestones, the youngest dated as Jurassic up to early Cretaceous based on fossils like Lithostrobus, Calpionella or Tintinopselae (Jovanović, 1957). The limestones occupy the central and southern parts of the map forming a large cone (Sunarić-Pamić et al., 1966).

Notable characteristics of limestones are karstification and well-developed fracture and crack systems as a

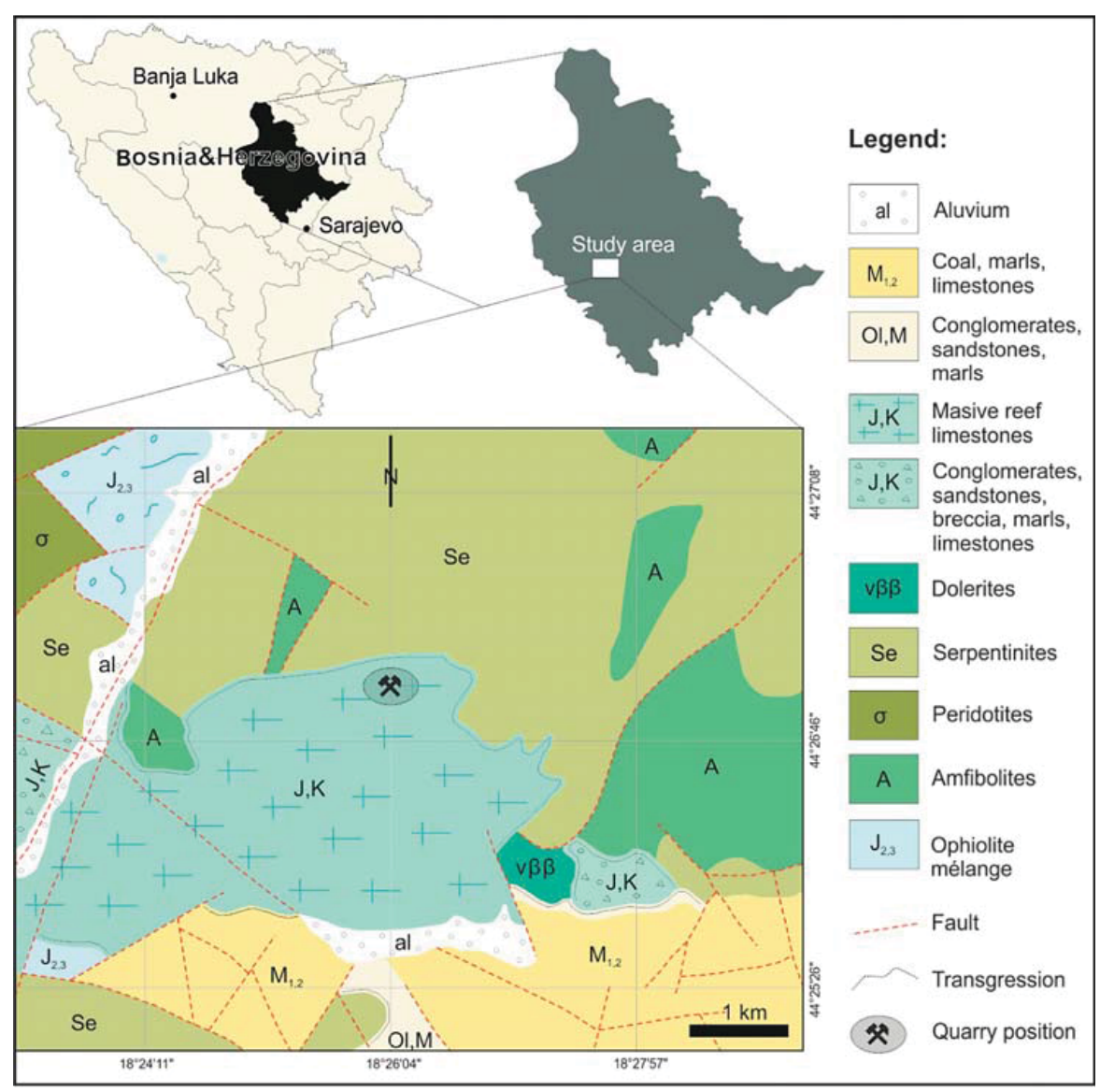

Figure 1: Location of the Vijenac Quarry with a geological map of the surrounding area (simplified after Sunarić-Pamić et al., 1966) 
result of several exogenous processes and multiple tectonic phases. Numerous caverns, cracks and fracture systems have fragmented limestones and destroyed the original stratification. They are often filled with surrounding materials and soil (Knežević et al., 1986; Miletović et al., 1978).

The northern and eastern part of the map is predominately composed of serpentinized rocks associated with medium-grade metamorphic rocks. Contact between the massive reef limestones and serpentines is tectonic and well differentiated, with crushed contact zones ranging from 1 to 3 m (Knežević, et al., 1986; Miletović et al., 1978).

Ophiolite mélange associated with genetically related sedimentary sequences represents the most characteristic and widespread subunit of the Internal Dinarides (Pamić et. al., 1998; Pamić et. al., 2002, Karamata, 2006). This chaotic tectono-sedimentary mixture is made up of detached 'pocket' to 'mountain' size blocks and boulders of oceanic crust along with the Palaeozoic to Jurassic carbonates and clastic sedimentary rocks (Trubelja \& Marchig, 1995; Tari, 2002).

A geological column (see Figure 2) of the wider quarry area presents general relations of the lithological sequences in correlation with the tectonostratigraphic characteristics of the DOZ. The earliest deposits belong to the Early-Middle Jurassic sediments $\left(\mathrm{J}_{1,2}\right)$ whose composition includes marls, limestones and radiolarites (Vishnevskaya et al., 2009), overthrusted by ophiolite mélange $\left(\mathrm{J}_{2.3}\right)$ (Šegvić et al., 2014).
Tithonian - Early Cretaceous / Late Barremian - Early Aptian overstep sequence of the Pogari Formation (Jovanović 1957, 1961; Hrvatović, 2006, respectively) unconformably overlie ophiolite mélange, including the igneous-metamorphic sequence. The Pogari Formation is composed mainly of unsorted marine conglomerates and breccias, containing fragments of re-deposited ophiolites and exotic reddish granites, which grade into lithic sandstones that laterally interfinger with reef Tithonian - Berriasian massive limestones (Jovanović, 1957; 1961; Pamić et al., 1966).

\section{Materials and methods}

Eight samples were chosen for macro- and micropetrography analyses. Based on these results, three samples were further chosen for in-depth analyses using $\mathrm{X}$-ray diffraction (abbr. XRD) and atomic absorption spectroscopy (abbr. AAS; Table 1). The investigation was completed in the Laboratory for analysis of geological materials (LaGEMA) at the Faculty of Mining, Geology and Petroleum Engineering, of the University of Zagreb.

\subsection{Micropetrography}

Thin sections of 8 concretion samples from the Vijenac Quarry were examined microscopically using a Leica DM LSP stereo-microscope under magnifications of 40,100, 400 and $600 \times$. The microscope is equipped with a Leica DC 100 digital camera and Leica Qwin im-

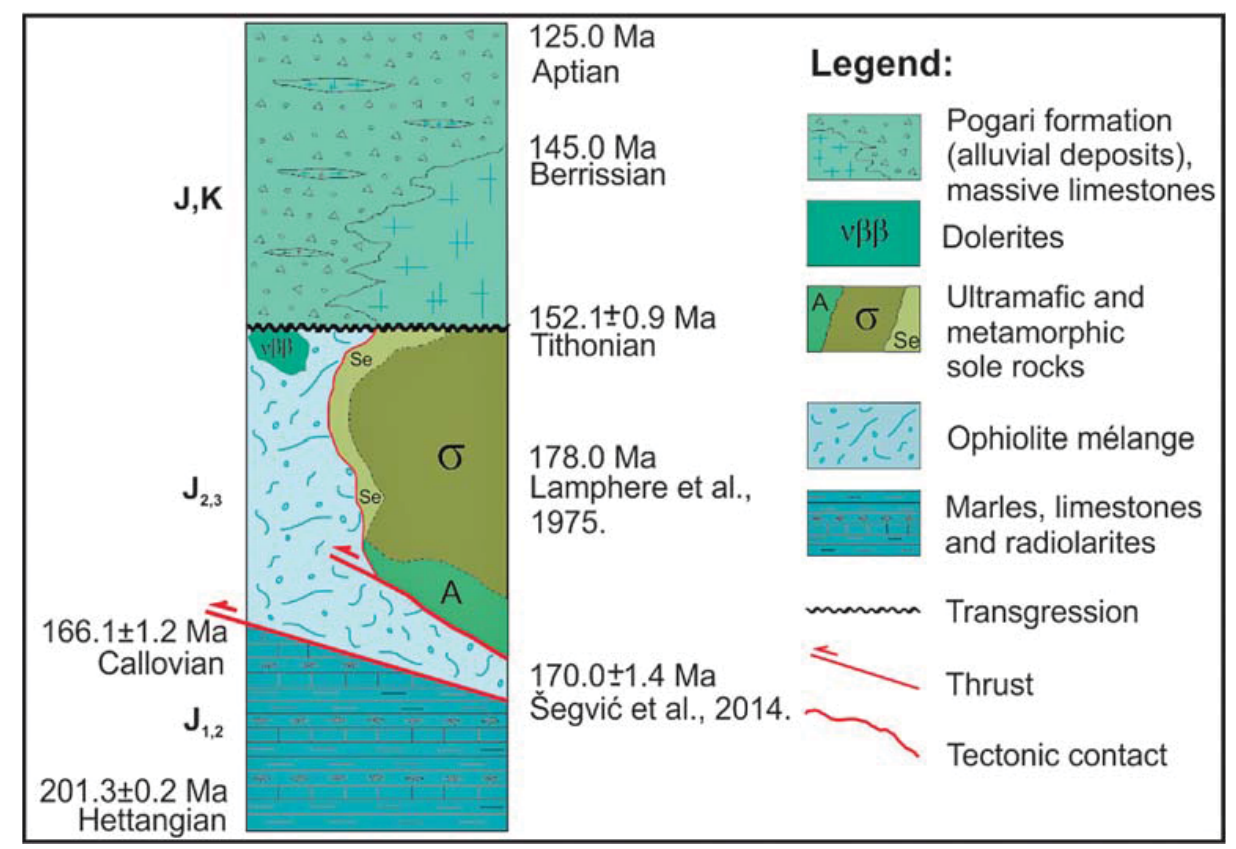

Figure 2: A geological column showing relationships between subgroups of the Dinaric Ophiolite Zone, including overstep sequences (compiled after Hrvatović, 20o6; Jovanović, 1961; Vishnevskaya et al. 2009, Šegvić et al., 2014) 

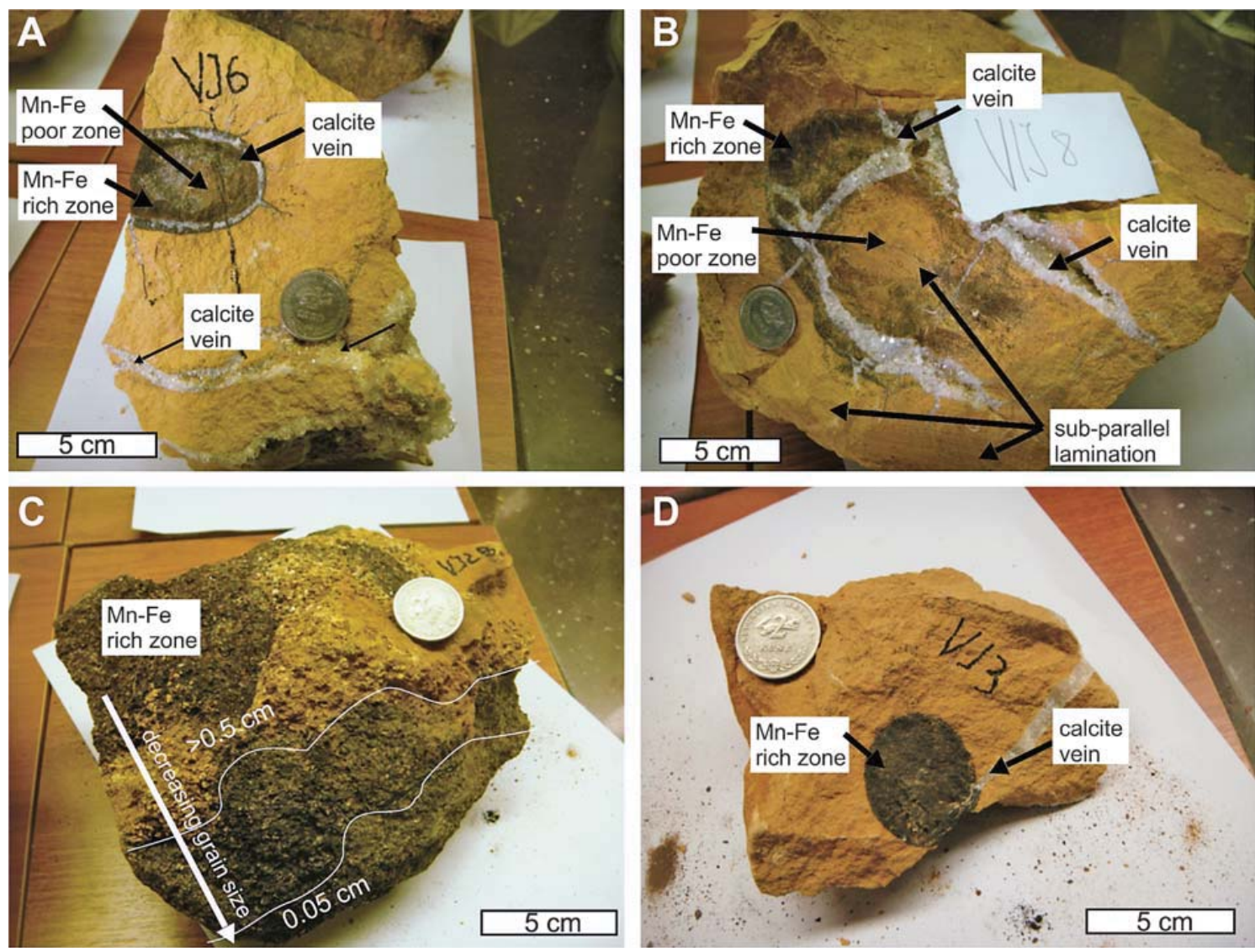

Figure 3: A) Ellipsoidal concretion, with weak zonation, $7 \mathrm{~cm}$ in diameter, surrounded by small calcite veins that are radiating outward from concretion. B) Fine-grained, laminated sandstone hosting round concretion with clearly expressed zoning, crosscut by veinlets filled with calcite, $10 \mathrm{~cm}$ in diameter. C) The black portion of the sample is actually a part of large, uniform concretion hosted by coarse-grained, graded sandstone. D) Compact, ellipsoidal concretion, $4 \mathrm{~cm}$ in diameter.

age analysis software (IM 50 v.1.20). The grain size is determined using a standard calibration micrometre scale. Samples were subjected to staining in order to determine the type of carbonates mineral present (Evamy and Shearman, 1962). Carbonates were immersed in a solution of potassium ferricyanide $\mathrm{K}_{3} \mathrm{Fe}(\mathrm{CN})_{6}$ with concentrated $\mathrm{HCl}$ and Alizarin red $\mathrm{S} \mathrm{C}_{14} \mathrm{H}_{8} \mathrm{O}_{4}$ with a diluted hydrochloric acid $(\mathrm{HCl} / 8)$ for 15 seconds and there upon being repeatedly immersed for 15 seconds in the solution Alzarin red $\mathrm{S}$ with a diluted hydrochloric acid $(\mathrm{HCl} / 8)$. Finally, the samples were washed with distilled water.

\section{2. $A A S$}

Based on macroscopic determination, samples VJ-1, VJ-5 and VJ-6 were selected for the atomic absorption spectroscopy and prepared by means of the sequence extraction analysis (abbr. SEA) and gravimetric analysis (see Table 1). Bulk samples of the selected concretion were powdered in an agate mortar.

Sequence extraction analysis according to Rauret (1999) consists of three steps. For our purposes the first two steps of SEA were prepared for analyses:
Table 1. List of samples and conducted analyses

\begin{tabular}{|l|c|c|c|c|}
\hline Sample & Macropetrography & Micropetrography & XRD & AAS \\
\hline VJ-1 & + & + & + & + \\
\hline VJ-2 & + & + & & \\
\hline VJ-3 & + & & & \\
\hline VJ-4 & + & & & \\
\hline VJ-5 & + & + & + & + \\
\hline VJ-6 & + & + & + & + \\
\hline VJ-7 & + & + & & \\
\hline VJ-8 & + & + & & \\
\hline
\end{tabular}

i. Carbonate leaching: during the first step acetic acid $\mathrm{CH}_{3} \mathrm{COOH}$ was used to extract the carbonate-bound fraction. The extracted solution was used for the determination of $\mathrm{Ca}$ and $\mathrm{Mg}$ through the AAS method.

ii. Fe-Mn oxyhydroxide leaching: within the second step, $\mathrm{Fe}$ and $\mathrm{Mn}$-oxide bound phases were extracted using hydroxylamine hydrochloride $\mathrm{HONH}_{2} \cdot \mathrm{HCl}$, acetate $\mathrm{CH}_{2} \mathrm{COOH}^{-}$and $\mathrm{HNO}_{3}$. The extracted solution was used for the determination of $\mathrm{Cr}, \mathrm{Fe}, \mathrm{Mn}$ and Ni through the AAS method. 

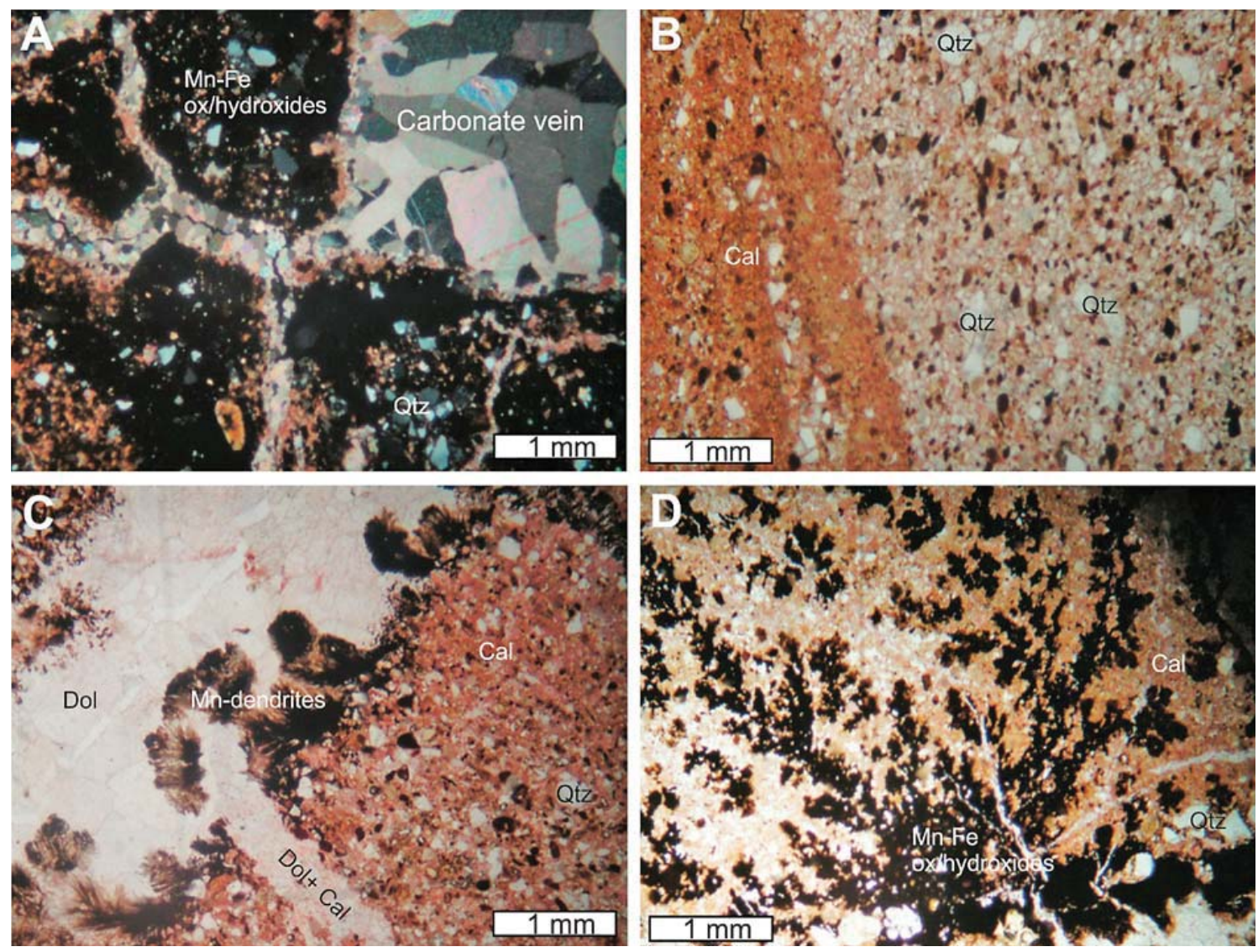

Figure 4: A) Two generations of calcite veins large crystals are $1^{\text {st }}$ generation, while small crystals are $2^{\text {nd }}$ generation.

B) Gradation of sandstones embedding concretion. Black parts are Fe-Mn minerals within cement. C) Mn-dendrites after partially dolomitized veins (stained sample). D) Mn-dendrites after sandstones with calcite matrix.

(Cal - Calcite; Dol - Dolomite; Qtz - Quartz).

Table 2. Elements concentration in the concretions given in percentages. Elements are determined as follows: ${ }^{\text {SEA }}$ using sequence extraction analysis; LOI using gravimetric analyses.

\begin{tabular}{|l|c|c|c|}
\hline Oxides wt.\% & VJ-1 & VJ-5 & VJ-6 \\
\hline $\mathrm{MnO}$ & 9.04 & 22.98 & 22.47 \\
\hline $\mathrm{FeO}$ & 8.10 & 5.40 & 6.95 \\
\hline $\mathrm{CaO}$ & 54.01 & 57.34 & 59.47 \\
\hline $\mathrm{NiO}$ & 0.25 & 1.01 & 0.63 \\
\hline $\mathrm{Cr}_{2} \mathrm{O}_{3}$ & 0.01 & 0.01 & 0.01 \\
\hline $\mathrm{MgO}$ & 0.17 & 0.17 & 0.17 \\
\hline $\mathrm{LOI}$ & 1.30 & 1.50 & 2.30 \\
\hline $\mathrm{Residue}$ & 27.12 & 11.59 & 8.0 \\
\hline $\mathrm{SUM}$ & 100.00 & 100.00 & 100.00 \\
\hline $\mathrm{Elements} \mathrm{wt. \%}$ & $\mathrm{VJ}-1$ & $\mathrm{VJ}-5$ & $\mathrm{VJ}-6$ \\
\hline $\mathrm{Mn}$ & 7.00 & 17.70 & 17.40 \\
\hline $\mathrm{Fe}$ & 6.30 & 4.20 & 5.40 \\
\hline $\mathrm{Ca}$ & 38.60 & 41.00 & 42.50 \\
\hline $\mathrm{Ni}$ & 0.25 & 1.01 & 0.63 \\
\hline $\mathrm{Cr}$ & 0.01 & 0.01 & 0.01 \\
\hline $\mathrm{Mg}$ & 0.10 & 0.10 & 0.10 \\
\hline $\mathrm{LOI}$ & 1.30 & 1.50 & 2.30 \\
\hline
\end{tabular}

An Analyst 700 atomic absorption spectrometer equipped with an air-acetylene burner was used for the determination of $\mathrm{Ca}, \mathrm{Fe}, \mathrm{Mg}, \mathrm{Mn}$ and $\mathrm{Ni}$ concentrations from the previously acquired solutions from sequence analyses. All chemicals were provided by the analyticalreagent grade (Merck). Distilled-deionized water was used throughout. Standard solutions needed for the preparation of calibration curves were made fresh-daily by diluting stock solutions of $\mathrm{Ca}, \mathrm{Cr}, \mathrm{Fe}, \mathrm{Mg}, \mathrm{Mn}, \mathrm{Ni}$. Loss of ignition (LOI) was performed at a temperature of $430^{\circ} \mathrm{C}$ and recalculated using gravimetry. The results are shown in Table 2.

\section{3. $X R D$}

Concretion samples VJ-1, VJ-5 and VJ-6 were powdered and measured using a Philips vertical X-ray goniometer (type $\mathrm{X}^{\prime}$ Pert) equipped with a $\mathrm{Cu}$ tube and graphite crystal monochromator with the following experimental conditions: $40 \mathrm{kV}, 40 \mathrm{~mA}$, primary beam divergence $1 / 4^{\circ}$, continuous scan (step $0.02^{\circ} 2 \theta / s$ ) three times (air-dried conditions):

1. Original, non-treated sample,

2. After carbonate leaching,

3. After Fe-Mn oxyhydroxide leaching. 
Table 3. Correlation of the mineral composition based on micropetrography and XRD analyses (Abbreviation: Alm - almandine, Brt - barite, Cal - calcite, Dol - dolomite, Gr - graphite, Gt - goethite, Hem - hematite, Kln - kaolinite, Mnt - montmorillonite, Ms - muscovite, Prp - pyrope, Qtz - quartz, Tkn - takanelite, Tod - todorokite). Mineral abbreviations after International Mineralogical Association (IMA).

\begin{tabular}{|l|c|c|c|c|}
\hline \multirow{2}{*}{ Sample } & \multirow{2}{*}{ Micropetrography } & \multicolumn{3}{|c|}{ XRD } \\
\cline { 3 - 4 } & & Original sample & Carbonate leaching & Fe-Mn oxyhydroxide leaching \\
\hline VJ-1 & Cal, Dol, Qtz \pm Gr, Fe-Cal & Qtz, Cal, Tkn & Qtz, Tkn \pm Gt, Ms & Qtz \pm Mnt, Ms \\
\hline VJ-5 & $\begin{array}{c}\text { Cal, Dol, Qtz } \pm \text { Rt, Gr, } \\
\text { Fe-Cal }\end{array}$ & $\begin{array}{c}\text { Qtz, Cal, Tod, } \\
\text { Tkn } \pm \text { Hem, Gt }\end{array}$ & $\begin{array}{c}\text { Qtz, Tkn, Tod } \pm \text { Kln Hem, } \\
\text { Mnt }\end{array}$ & Qtz \pm Kln, Hem, Alm \\
\hline VJ-6 & Cal, Dol, Qtz \pm Rt & Qtz, Cal, Tod, Tkn \pm Hem & Qtz, Tkn, Tod \pm Hem, Gr & Qtz \pm Brt, Prp, Hem \\
\hline
\end{tabular}
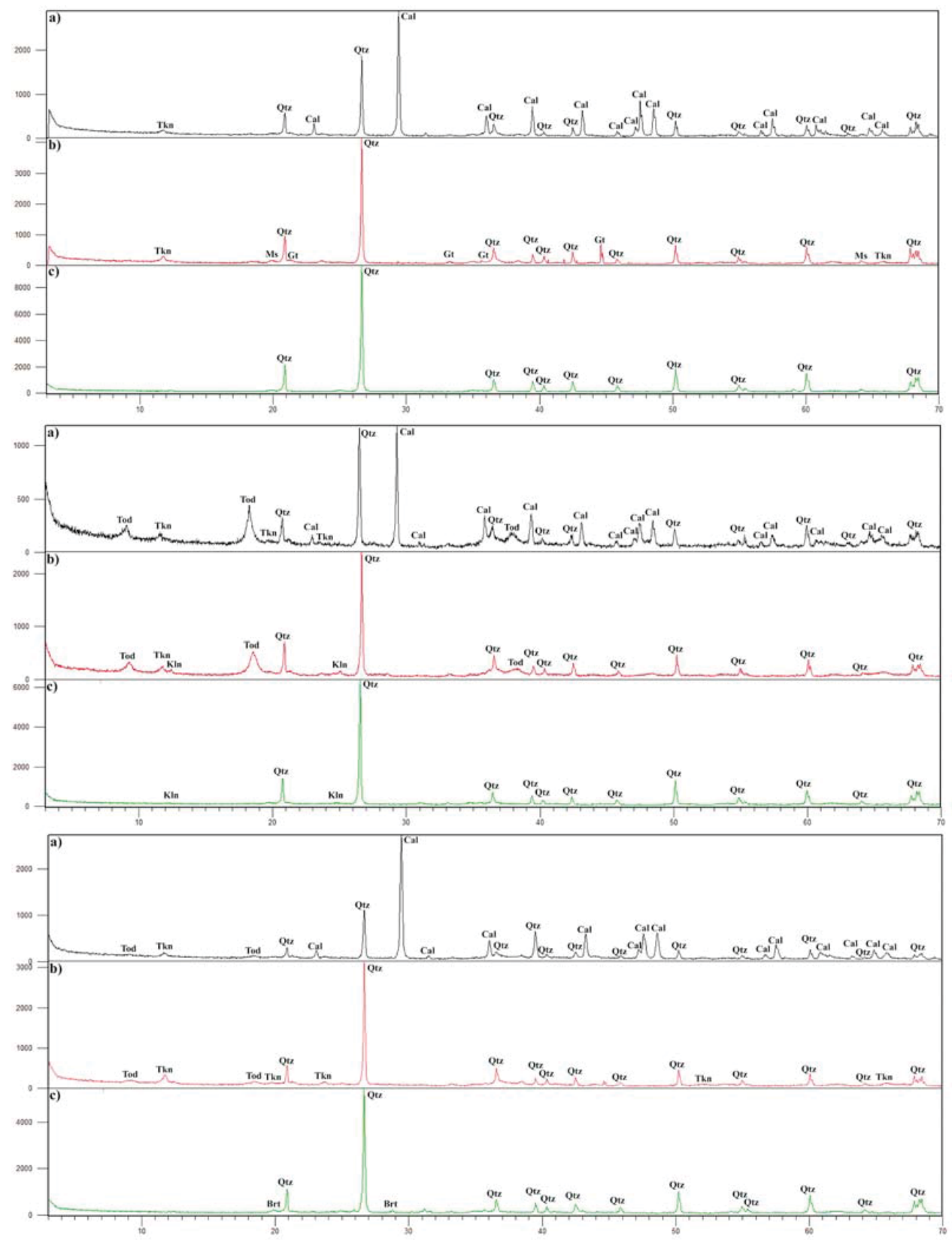

Figure 5: Comparative results of XRD analysis for samples VJ-1 (first), VJ-5 (second) and VJ-6 (third part). a) Original, non-treated sample b) Sample treated to remove carbonates c) Sample treated to remove Fe-Mn oxyhydroxides (procedure described under Section 3 - Materials and methods). 
Obtained spectres were analysed using X'Pert HighScore plus software. The results are presented in Table 3 .

\section{Results}

\subsection{Macropetrography}

The observed concretions predominantly show spherical or symmetrical shapes with diameters varying from 2 to $20 \mathrm{~cm}$. Some concretions show a non-symmetrical narrowing having a pear-like shape, which probably reflects space deficiencies at the time of their formation. Concretion internal structure (i) shows a weak or distinct zonation, likely resulting from different concentration gradients of Fe-Mn oxyhydroxides. This zonation is visible on macroscopic samples as a variation of colour from lightly greyish brown (probably representing a FeMn poor zone) to almost fully black zone (probably representing a Fe-Mn rich zone) (see Figures 3A; B) or (ii) appears as compact and uniform (see Figures 3C; D). Most concretions are surrounded or crosscut by calcite veins (see Figures 3A; B) formed by later tectonic processes. The host rock was classified as greywacke sandstone (classification after Pettijohn et. al, 1972) (see Figures 3C; D) showing internal folding and distinct grain-size grading.

\subsection{Micropetrography}

The host rocks of the Fe-Mn concretions are classified as lithic greywacke that has a clastic texture with a clearly recognizable lamination. Layering and graded bedding is present in some of the samples (see Figure 4). Concretions contain the following mineral assemblages: (1) siliciclastic host rock assemblage (primary minerals) and (2) cement composed of Fe-Mn oxyhydroxides and carbonate (secondary minerals). The primary assemblage is composed of quartz $(\approx 60 \mathrm{vol} \%)$, opaque minerals, subordinate rutile $(\approx 30 \mathrm{vol} \%)$, lithic fragment $(\approx 10$ vol\%), and some chlorite and Fe-carbonate. The cement is composed of the Fe-Mn oxyhydroxides and calcite (see Figures 4A - D). Calcite also occurs within veins surrounding the Fe-Mn concretions, in two generations: a cm-thick calcite veins occur crosscut by the next generation of tiny calcite veinlets (see Figure 4C). Calcite in the vein and cement is subjected to partial dolomitization, as suggested by carbonate staining (see Figure 4D). This figure also shows the development of secondary Mn-dendrites within carbonate veinlets. Fe-Mn oxyhydroxides are further confirmed by XRD as hematite, takanelite ((Mn, $\left.\mathrm{Ca}) \mathrm{Mn}_{4} \mathrm{O}_{9} \cdot \mathrm{H}_{2} \mathrm{O}\right)$ and todorokite $((\mathrm{Na}$, $\mathrm{Ca}, \mathrm{K}, \mathrm{Ba}, \mathrm{Sr})_{1-\mathrm{x}}(\mathrm{Mn}, \mathrm{Mg}, \mathrm{Al})_{6} \mathrm{O}_{12} \cdot 3-4 \mathrm{H}_{2} \mathrm{O}$ ) (detailed description within section 4.4.).

\section{3. $A A S$}

Results of the AAS analyses show that the bulk composition of the concretions consists of $\mathrm{Mn}$ (7-17 wt.\%),
$\mathrm{Ca}(39-42$ wt. \%) and $\mathrm{Fe}(4-6$ wt.\%) while the rest corresponds to silica residue. The concentration of $\mathrm{Mn}$ is considerably lower in the sample VJ-1 in contrast to samples VJ-5 and VJ-6. The abundance of $\mathrm{Ca}$ and $\mathrm{Fe}$ in all three samples did not significantly vary. To assess the influence of the surrounding ophiolite rocks, the concentrations of $\mathrm{Ni}, \mathrm{Cr}, \mathrm{Mg}$ were measured (see Figures $\mathbf{1}$ and 2). Their percentage was found to be below $1 \mathrm{wt} \%$ (see Table 2).

\section{4. $X R D$}

According to X-ray diffraction analysis, manganese minerals and quartz are the dominant phases in the concretions (see Figure 5). Results of micropetrography for samples VJ-1, VJ-5 and VJ-6 are presented along the results of XRD analysis in Table 3.

All three original samples show similar mineral paragenesis, consisting of quartz, calcite and Mn oxyhydroxide phases (todorokite, takanelite). Samples deprived of carbonates show analogue assemblages (without calcite), while the intensities of the peaks of $\mathrm{Mn}$ minerals are somewhat accentuated. Following the removal of Fe-Mn oxyhydroxides the weak reflexes of different types of clay minerals (most likely kaolinite or montmorillonite), and in some cases minerals from garnet group or barite may be identified.

\section{Discussion}

\subsection{Mineralogical and chemical composition of concretions}

Petrographic, chemical and XRD analyses of Fe-Mn concretions had pointed to their twofold composition. The first type is consisted of Mn-rich concretions with $\approx 17$ wt.\% of $\mathrm{Mn}$ and compact texture (VJ-5 and VJ-6), whereas the second type is made of $\mathrm{Mn}$-poor $(\approx 8 \mathrm{wt} . \%$ of $\mathrm{Mn}$ ) concretions with a porous texture (VJ-1). The amounts of $\mathrm{Cr}$ and $\mathrm{Fe}$ in both concretions are similar.

The described types of concretions, alongside with their mineralogical and chemical properties are given in Figure 6. Both concretion types are embedded within lithic greywacke inheriting previous sedimentary structures (see Figure 3B; C). The Vijenac Quarry concretions appear to be much larger in size (up to $20 \mathrm{~cm}$ in diameter) comparing to the available literature data for soils and sediments hosted concretions (Gasparatos 2005; 2012; 2013; Chan et al., 2007 and references therein).

The Mn-rich concretions occur in compact and ellipsoidal forms. Macroscopically one can identify quartz grains and lithic fragments up to $0.5 \mathrm{~cm}$ in size and cross-cutting calcite veins (see Figure 3). Micropetrography and XRD confirm the presence of quartz, calcite, dolomite, takanelite, todorokite and a minor amount of rutile, hematite and some other accessory minerals (see 


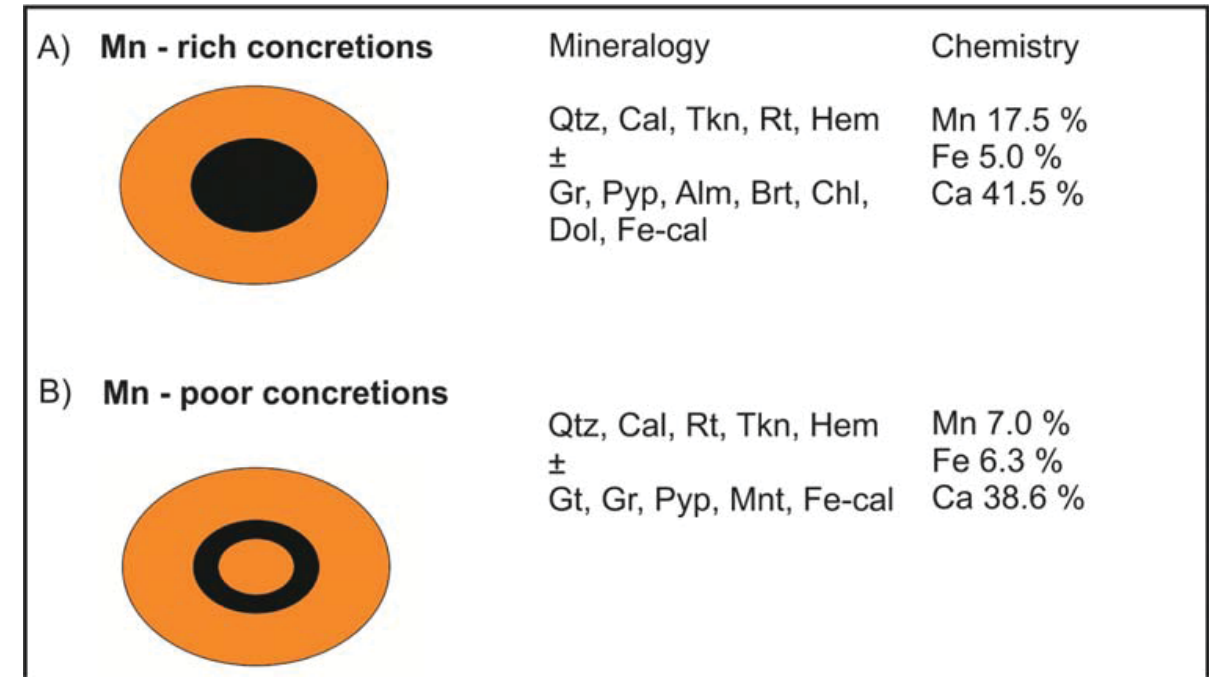

Figure 6: Schematic sketch of concretion types together with their mineralogical and chemical properties within the Vijenac Quarry: A) Mn-rich concretions and B) Mn-poor concretions. The orange parts show siliciclastic host rock assemblage (primary minerals) and the black part is cement composed of Fe-Mn oxyhydroxides (secondary minerals) (Abbreviation: Brt - barite, Cal - calcite, Dol - dolomite, Fe-cal - iron calcite, Gr - graphite, Gt - goethite, Hem - hematite, Mnt - montmorillonite, Ms - muscovite, Prp - pyrope, Qtz - quartz, Tkn - takanelite, Tod - todorokite). Mineral abbreviations after International Mineralogical Association (IMA).

Figure 6A). Concretions are enriched in $\mathrm{Mn}(\approx 17$ wt.\%), $\mathrm{Ni}$ (up to $0.8 \mathrm{wt} . \%$ ) and additionally containing $\approx$ 5 wt. $\%$ of Fe.

Mn-poor concretions have a mineralogical composition equal to Mn-rich concretions (see Figure 6B). They are low in the $\mathrm{Mn}(\approx 8 \mathrm{wt} . \%$ of $\mathrm{Mn}), \mathrm{Ni}(0.2 \mathrm{wt} . \%)$ and containing $\approx 6 \mathrm{wt} . \%$ of Fe.

$\mathrm{Ni}$ increase from $0.2 \mathrm{wt} . \%$ within the Mn-poor concretions until 0.8 wt. $\%$ within the Mn rich concretions. Similar trends had been observed by Gasparatos (2013 and references therein) where Ni content in Fe-Mn concretions positively correlates with a Mn-rich phase. The amounts of $\mathrm{Cr}(0.01 \mathrm{wt} . \%)$ and $\mathrm{Fe}(5-6 \mathrm{wt} . \%)$ within both Vijenac Quarry concretion types are uniform. According to the literature (Gasparatos, 2013 and references therein) an increased $\mathrm{Cr}$ value likely involves isomorphic substitution of $\mathrm{Cr}^{3+}$ with $\mathrm{Fe}^{3+}$, and therefore positively correlates with the amount of the Fe.

\subsection{Formation mechanisms of the Fe-Mn concretions}

Several general types of the Fe-Mn concretion forming mechanisms are plausibly related to different scenarios for the Vijenac Quarry concretion formation.

1. Freshwater and lacustrine Fe-Mn concretions can be developed as autochthonous phases during the freshwater and lacustrine sediments diagenesis, controlled by the upward migration of the pore water (Davison, 1982 and references therein). A selective solution of the Fe and Mn, caused by changes in redox conditions, later facilitated mixing and enrichment of pore water where concretions were developing. The presence of an increased amount of organic matter, characteristic for this type of environment, affects the enrichment of the pore water as well. The main mineral of the freshwater Fe-Mn concretion is goethite, while Mn phases are represented by todorokite, psilomelane and birnessite. These concretions are characterised by variations in their $\mathrm{Fe} / \mathrm{Mn}$ ratios, concentric bands of alternating $\mathrm{Fe}-$ rich (lighter) and Mn-rich (darker) laminations, increased content of organic matter and low content of microelements such as $\mathrm{Co}, \mathrm{Mn}, \mathrm{Mo}, \mathrm{Ni}$, Ti (Davison, 1982 and references therein). Additionally, Fe-rich laminas are associated with silica, phosphate and arsenic, whereas Mn-rich laminas associated with $\mathrm{Cu}, \mathrm{Co}, \mathrm{Ni}$ and $\mathrm{Zn}$. This type of formation mechanisms was considered for the Vijenac Quarry concretions, due to the presence of goethite and todorokite and subordinate amounts of analysed microelements $(\mathrm{Cr}, \mathrm{Ni})$.

2. The Fe-Mn concretions found in soil are formed in the exchanging oxidation and reduction conditions within the soil sequence. Concretions in soil are extremely firm, rounded morphologic bodies, formed through the process of reduction, relocation and oxidation of the Fe and Mn. There are two periods of formation. During the moist period, the percentage of $\mathrm{Fe}^{3+}$ and $\mathrm{Mn}^{3+/ 4+}$ is lowered and growth of concretion is ceased. During the dry period, the percentage of oxygen is increasing, subsequently triggering the onset of $\mathrm{Fe}$ and $\mathrm{Mn}$ precipitation within the matrix. This type of concretion has an infill of Fe and Mn oxides located between fragments of matrix, skeletons of grain, fossils, clay minerals and pores. Formation is a long-term process, specific 
for some types of soil. Other minerals that can be found in concretions except Fe-Mn oxyhydroxides, quartz and clay minerals (Gasparatos, 2012). This type of formation mechanisms was considered for the Vijenac Quarry due to the presence of secondary Fe and Mn minerals and clay in the matrix and primary quartz within clastic assemblage. However, these types of concretions usually have a seed nucleus around which the mineralization started and are up to $4 \mathrm{~cm}$ in size. Concretions from the Vijenac Quarry are larger and our investigation did not find traces of initial fragment.

3. The Fe-Mn concretions in sandstones occur as the result of precipitations of the Fe-Mn oxyhydroxides from groundwater. Due to circulation, the exchange of oxidation-reduction phases take place. Concretion is usually found within predominantly clastic sandstones with good circulation of groundwater or fluid. These types of concretions usually lack a nucleus. A concentric structure can be observed within larger samples, whereas small concretions sometimes show massive structure (Chan et al., 2007). This formation mechanism was considered for the Vijenac Quarry concretions for the several reasons: (i) host rock lithology (sandstones); (ii) missing nucleus of the studied concretions; (iii) massive structure of the small concretions and complex structure including rinds and multiple layers of the large concretions (see Figure 3).

\subsection{Origin of concretions within the Vijenac Quarry}

Based on a detailed petrographic, mineralogical and chemical study, the formation of the Vijenac Quarry concretions is hypothesised to have proceeded in three separate stages. Here we briefly summarize the evidence supporting this assumption. According to the literature, concretions from the Vijenac Quarry show similarities to the concretions formed in soils and sandstones. Similar mineralogy (the Fe-Mn oxyhydroxides and indicated clay minerals) can be precipitated during the exchange of redox potential in soil moist vs dry periods), whereas their sedimentary host, structure and missing nucleus show similarities to the concretions formed in sandstones. Chemical analysis performed on concretions VJ-1, VJ-5 and VJ-6, enabled classification into two types: 1) Mnrich concretions ( $\mathrm{VJ}-5$ and $\mathrm{VJ}-6$ ) having $\mathrm{Mn} \approx 17.5 \mathrm{wt} . \%$, $\mathrm{Fe} \approx 5$ wt. $\%$ and 2 ) Mn-poor concretion (VJ-1) having $\mathrm{Mn} \approx 7.5 \mathrm{wt} . \%, \mathrm{Fe} \approx 6.3 \mathrm{wt} . \%$. Both types share similar proportions of other analysed microelements as well as similar mineralogical composition. According to the $\mathrm{pH} /$ Eh diagrams for the recognised $\mathrm{Fe}$ and $\mathrm{Mn}$ species, coexisting $\mathrm{Fe}$ and $\mathrm{Mn}$ minerals would precipitate under the conditions of $\mathrm{pH}=4-6$ and $\mathrm{Eh}=0.3-1 \mathrm{~V}$ (Takeno, 2005). Takeno (2005) diagram is used under the assumption of saturated conditions for Fe and Mn (i.e. the total concentration of $\mathrm{Mn}$ of 10 at $-10 \mathrm{~mol} / \mathrm{L}$ and the total Fe concentration of 10 at $-10 \mathrm{~mol} / \mathrm{L})$. Concretions generally show the following stages of development:

\subsubsection{Stage 1 - Fe-Mn concretion growth}

According to literature observations summarised in Section 5.2., concretion development begins with the circulation of groundwater enriched with the Fe and Mn through the porous rocks, followed by periodic precipitation of the Fe-Mn oxyhydroxides, related to the oscillation of redox potential. Periodical precipitation and variations of the $\mathrm{Fe}$ and $\mathrm{Mn}$ within groundwater led to the development of concentric structures (zones), recognisable in most of the Vijenac Quarry concretions (see Figure 3). Zones have different proportion of the Fe/Mn oxyhydroxides, generally increasing with macroscopically and microscopically visible darkening (see Figures 3; 4). According to Gasparatos (2012 and references therein) Mn precipitated at lower $\mathrm{pH}$ and under a more oxidised environment comparing to $\mathrm{Fe}$ and thus small variations of $\mathrm{pH}$ and Eh conditions during periodical oscillation of groundwater would largely influence the dynamics of precipitation.

\subsubsection{Stage 2 - Carbonatization}

The second phase is characterised by the development of microtectonic-related veins and veinlets filled with secondary carbonates (mainly calcite), usually cross-cutting the concretion zonation. In some cases, secondary carbonate fractures and veinlets follow the concentric structure of concretion (see Figure 3A). Here, we had recognised two stages of veinlet development; first generation calcite within $>1 \mathrm{~cm}$ thick veins containing up to $1.5 \mathrm{~mm}$ in size is crosscut by the second generation of tiny carbonate veinlets containing crystals about $0.1 \mathrm{~mm}$ in size. The appearance of the secondary Mn-dendritic structures is related to the first generation of carbonates (see Figure 4D). Carbonatization is also recognisable within the matrix of the concretions. Some manganese carbonates occur as well, as evidenced by XRD (see Table 3).

\subsubsection{Stage 3 - Dolomitization}

Finally, large calcite grains within first generation veins are subjected to partial dolomitization, as proven by the method of carbonate staining (see Figure 4D). Dolomitization is also recognized within the matrix.

\subsection{Concretions age and spatial correlation within the Dinarides}

The studied concretions are formed within consolidated sandstones inheriting their sedimentary textures. Macro and micropetrography of the concretions shows bedding, internal folding and micro-faulting infilled with carbonates. Observed structural features continue without a break to the host greywacke sandstone pointing to a late origin of concretions, most likely related to the uplift of the Pogari Formation toward a level of meteoric water system. According to Pamić et al. (1998) compressional events throughout Eocene and Oligocene 
were accompanied by the several uplift episodes of the Dinarides. So far, Vijenac Quarry concretions are a single report of the Fe-Mn concretions within the Internal Dinaride units.

The Upper Cretaceous limestones within the External Dinaride formations have reported records of the Mn. It appears that Late Cretaceous backshore limestones from the island of Dugi Otok, Croatia, host an unusual occurrence of Mn-hydrated oxide mineralization in the form of botryoidally and globular, fine-laminated concentric aggregates consisting of todorokite and accessory MnO·OH (Lugović et al., 2008). The authors suggested that $\mathrm{Mn}$ has been leached and mobilized from the Late Pleistocene sea floor sediments located around 50 nautical miles south of Dugi Otok, therefore the Mn occurrence is related to the uplift of buried sediments into a meteoric water system. Furthermore, (Posilović et al. 2016) discovered the variously shaped and internally zoned siliceous-carbonate concretions in Southern Croatia (Šubir hill tunnel; Pojezerje municipality area) within the Upper Cretaceous carbonate deposits (latest Cenomanian / Early Turonian). Their carbon isotope composition corresponds to the globally known CenomanianTuronian 'Oceanic Anoxic Event', therefore corresponding to early (syn) diagenetic origin. Concretions are of different size, from less than $1 \mathrm{~cm}$ to more than $20 \mathrm{~cm}$ in diameter. Another late diagenetic appearance of carbonate concretions is recorded within the Early Cretaceous limestones and dolostones of the Tounj Cave, near Ogulin, in Central Croatia (Lacković, 1998).

\section{Conclusion}

In this study, we had investigated the Fe-Mn concretions embedded within the border zone of the Vijenac Quarry, composed of tectonically disturbed siltite and sandstone. The quarry is a part of Dinaric overstep sequences (the Pogari Formation) of Late Jurassic / Early Cretaceous to Late Cretaceous age.

According to petrographic, chemical and mineralogical analyses, concretions may be grouped into Mn-rich and Mn-poor concretions having $17 \mathrm{wt} . \%$ and $8 \mathrm{wt} . \%$ of Mn respectively, 5-6 wt.\% of $\mathrm{Fe}$ and consisting of quartz, calcite, dolomite, takanelite and todorkite. The content of $\mathrm{Ni}$ in concretions positively correlates with $\mathrm{Mn}$ abundances whereas $\mathrm{Cr}$ correlates with $\mathrm{Fe}$.

According to the $\mathrm{pH} /$ Eh diagrams, coexistence of the Fe-Mn oxyhydroxides would precipitate under the conditions of $\mathrm{pH}=4-6$ and $\mathrm{Eh}=0.3-1 \mathrm{~V}$ (Takeno, 2005). Petrographic and mineralogical study points to the development of Fe-Mn concretions in three stages:

1) The Fe-Mn concretion growth and development of zonal structures related to the oscillation of redox potential and variation of Fe and Mn within circulating groundwater through the porous Vijenac Quarry greywackes.
2) Two generations of carbonates developed within microtectonically-related veins and veinlets crosscutting surrounding the concretions or within the concretion matrix. First generation veins contain secondary Mn-dendritic structures.

3) Large calcite grains within first generation veins are subjected to partial dolomitization, also recognized within the concretion matrix.

The Vijenac Quarry concretions are similar to the FeMn concretions within sandstones occurring as a result of precipitations of Fe-Mn oxyhydroxides from oscillating groundwater. This formation mechanism was considered for the Vijenac Quarry concretions for several reasons: (i) host rock lithology (sandstones); (ii) missing nucleus of the studied concretions; (iii) the massive structure of the small concretions and complex structure including rinds and multiple layers of the large concretions. The studied concretions are formed within consolidated sandstones inheriting their sedimentary textures most likely related to the uplift of the Pogari Formation toward a level of the meteoric water system. Formation of the concretions might have occurred during the Eocene to Oligocene uplift of the Dinarides.

\section{Acknowledgement}

The authors acknowledge Neven Tadej for advising during the XRD interpretation. Michaela Hruskova Hasan and Nada Čegec assisted during chemical and AAS analyses. Reviewers comments significantly improved early versions of the manuscript. The eEditorial handling of Uroš Barudžija is highly appreciated.

\section{References}

Bender, M. L., Ku, T.-L., Broecker, W. S, (1966): Manganese Nodules: Their Evolution. Science, 151, 325-328.

Bonatti, E. and Nayudu, R. (1965): The origin of manganese nodules on the ocean floor. American Journal of Science 263, 17-39.

Chan, M. A., Ormo, J., Park, A. J., Stich, M., Souza-Egipsy, V. and Komatsu, G. (2007): Models of iron oxide concretion formation: field, numerical, and laboratory comparisons. Geofluids, 7, 1-13.

Chiari, M., Baumgartner, P.O., Bernoulli, D., Bortolotti, V., Marcucci, M., Photiades, A.D. and Principi, G. (2013): Late Triassic, Early and Middle Jurassic Radiolaria from ferromanganese-chert "nodules" (Angelokastron, Argolis, Greece): evidence for prolonged radiolarite sedimentation in the Maliac-Vardar Ocean. Facies, 59, 391-424.

Davison, W. (1982): Transport of iron and manganese in relation to the shapes of their concentration-depth profiles. Hydrobiologia, 91, 466-471.

Dimitrijević, M.D. and Dimitrijević, M.N. (1973): Olistostrome mélange in the Yugoslavian Dinarides and late Mesozic plate tectonics. Journal of Geology, 81, 328-340. 
Evamy, B.D. and Shearman, D.J. (1962): The application of chemical staining techniques to the study of diagenesis in limestones. Proc. Geoligal Society, London, 1599, 102.

Gasparatos, D., Tarenidis, D., Haidouti, C. and Oikonomou, G. (2005): Microscopic structure of soil Fe-Mn nodules: environmental implication. Environmental Chemistry Letters, 2, 175-178.

Gasparatos, D. (2012): Fe-Mn Concretions and Nodules to Sequester Heavy Metals in Soils. In: E. Lichtfouse et al. (eds.): Environmental Chemistry for a Sustainable World: Volume 2: Remediation of Air and Water Pollution. Springer, Athena, 443-459, $548 \mathrm{p}$.

Gasparatos, D. (2013): Sequestration of heavy metals from soil with Fe-Mn concretions and nodules. Environmental Chemistry Letters, 11, 1, 1-9.

Glasby, G. P. (1972): The mineralogy of manganese nodules from a range of marine environments. Marine Geology, $13,57-72$.

Hrvatović, H. (2006): Geological guidebook through Bosnia and Herzegovina. Geological Survey of Bosnia and Herzegovina, $156 \mathrm{p}$.

Jovanović, R. (1957): Pregled razvoja mezozoika i neki novi podaci za stratigrafiju i tektoniku NR $\mathrm{BiH}$ (Review on the development of Mesosoic and new data for stratigraphy and tectonics of Bosnia and Herzegovina). II ${ }^{\mathrm{ème}}$ Congres des Geologues de Yougoslavie, Budva 8.9.-14.9.1957. L'union des sociétés géologique de la R.F.P. de Yougoslavie, Sarajevo, 38-63. (in Montenegrin)

Jovanović, R. (1961): Prilog poznavanju prostranstva i facija mezozoika unutrašnje zone Dinarida u NR BiH (A contribution to knowledge on the locations and facies of the Mesosoic within Internal Dinarides of Bosnia and Herzegovina). III ${ }^{\text {ème }}$ Congres des Geologues de Yougoslavie, Budva 27.9.-4.10.1959. L'union des sociétés géologique de la R.F.P. de Yougoslavie, Titograd, 148-176. (in Montenegrin)

Karamata, S. (2006): The geological development of the Balkan Peninsula related to the approach, collision and compression of Gondwana and Eurasian units. In: Robertson, A.H.F. and Mountrakis, D. (eds.): Tectonic development of the Eastern Mediterranean Region. Geological Society, London, Special Publications, 260, 155-178.

Knežević, V., Aba, S., Kalajlić, Z., Hodžić, F. and Tomić, M. (1986): Elaborat o rudnim rezervama krečnjaka na ležištu Vijenac kod Lukavca. FSD RO krečnjaka «Vijenac», Lukavac (Study on the reserves of Vijenac Quarry limestone deposit near Lukavac), Soda Factory, Lukavac, 33p. (in Bosnian)

Lacković, D. (1998): Diagenetic Concretions from the Cave Clastic Sediment, Cave Tounj Quarry, Croatia. Acta Carsologica, 27, 2, 97-103.

Lugović, B., Altherr, R., Raczek, I., Hofmann, A.,W. and Majer, V. (1991): Geochemistry of peridotites and mafic igneous rocks from the Central Dinaridic Belt, Yugoslavia. Contribibutions to Mineralogy and Petrology, 106, 201-216.

Lugović, B., Šegvić, B. and Šegvić, T. (2008): Mn-crust todorokite mineralization on SW backshore Cretaceous limestones from the island of Dugi Otok (Central Adriatic, Croatia). Acta Adriatica, 49, 53-63.
Miletović, B., Radović, R., Baturić, I., Rokić, Lj. and Andrić, V. (1978): Studija određivanja zona opasnosti uslijed seizmičkih efekata na kamenolomu Vijenac, Tuzla. (Study on the seismically influenced zones of the Vijenac Quarry), Soda Factory, Lukavac. (in Bosnian)

Mozley, P.S. (2003): Diagenetic structures. Encyclopedia of Sediments and Sedimentary Rocks. Kluwer Academic Press, 219-225, 928 p.

Pamić, J., Sunarić-Pamić, O., Kapeler, I. and Olujić, J. (1966): Tumač Osnovne geološke karte SFRJ, 1:100.000, list Zavidovići. Institut za geološka istraživanja Sarajevo. (Explanations of Basic Geological Map SFRY - sheet Zavidovići). Geological Survey Belgrade. (in Croatian)

Pamić, J. (1982): Some geological problems of the Dinaride ophiolites and their associations. Earth Evolution Sciences, 2, 1, 30-35.

Pamić, J., Gušić, I. and Jelaska, V. (1998): Geodynamic evolution of the Central Dinarides. Tectonophysics, 297, 251268.

Pamić, J., Tomljenović, B. and Balen, D. (2002): Geodynamic and petrogenetic evolution of Alpine ophiolites from the central and northwest Dinarides: an overview. Lithos, 65, 113-142.

Pamić, J. (1997): The northernmost outcrops of the Dinaridic ophiolites; a case study of Mt. Kalnik. Acta Geologica Hungarica, 40, 37-56.

Photiades, A.D. (2010): Fe-Mn Nodular Concretions Associated with Middle Jurassic Oceanic Mélange (Argolis, Greece). Proceedings of the XIX CBGA Congress, Thessaloniki, Greece, Special Volume 99, 323-332.

Posilović, H., Fio Firi, K., Sremac, J., Cvetko Tešović, B. and Brajković, M. (2016): Authigenic silicious-carbonate concretions in Cenomanian-Turonian carbonates of southern Croatia; geochemical and biotic record. Facies 62, 28 https://doi.org/10.1007/s10347-016-0480-x

Rauret G., López-Sánchez J.F., Sahuquillo A., Rubio R., Davidson C., Ure A. and Quevauviller P. (1999): Improvement of the BCR three-step sequential extraction procedure prior to the certification of new sediment and soil reference materials. Journal of Environmental Monitoring, 57-61.

Seilacher, A. (2001): Concretions morphologies reflecting diagenetic and epigenetic pathways. Sedimentary Geology, 143, 41-57.

Sunarić-Pamić, O., Pamić, J., Kapeler, I., Olujić, J. and Zec, F. (1966): Osnovna geološka karta SFRJ, 1:100.000, list Zavidovići. Institut za geološka istraživanja Sarajevo ( $\mathrm{Ba}$ sic Geological Map SFRY - sheet Zavidovići). Geological Investigation Survey. (in Bosnian)

Šegvić, B. (2010): Petrologic and geochemical characteristics of the Krivaja-Konjuh ophiolite complex (NE Bosnia and Herzegovina) - petrogenesis and regional geodynamic implications. Ph.D. thesis, Ruprecht-Karls-Universität 1082 Heidelberg, Heidelberg, Germany, Published thesis.

Šegvić, B., Kukoč, D., Dragičević, I., Vranjković, I., Brčić, V., Goričan, Š., Babajić, E. and Hrvatović, H. (2014): New

The Mining-Geology-Petroleum Engineering Bulletin and the authors @, 2018, pp. 63-74, DOI: 10.17794/rgn.2018.3.7 
record of Middle Jurassic radiolarians and evidence of Neotethyan dynamics documented in a mélange from the Central Dinaridic Ophiolite Belt (CDOB, NE Bosnia and Herzegovina). Ofioliti 39, 1, 31-41.

Takeno, N. (2005): Atlas of Eh-pH diagrams. Geological Survey of Japan, Open File Report No.419, 287 p.

Tari, V. (2002): Evolution of the northern and western Dinarides: a tectonostratigraphic approach. EGU Stephan Mueller Special Publication Series, 1, 223-236.
Trubelja, F. and Marchig, V. (1995): Geokemijske karakteristike i porijeklo amfibolita ofiolitne zone u Bosni (Geochemical characteristics and origin of the amphibolite in the Ophiolite zone of Bosnia). Zbornik radova, 1. Hrvatski Geološki Kongres, Opatija, 2, 627-630.

Vishnevskaya V.S., Đerić N. and Zakariadze G.S. (2009): New data on Mesozoic radiolaria of Serbia and Bosnia, and implications for the age and evolution of oceanic volcanic rocks in the Central and Northern Balkans. Lithos, 108, 72-105.

\section{SAŽETAK}

\section{Mehanizmi za formiranje Fe-Mn konkrecija unutar kamenoloma Vijenac smještenoga u pojasu dinaridskoga ofiolitnog melanža}

Rudnik Vijenac, smješten u blizini Tuzle, Federacija Bosne i Hercegovine, sastoji se od karbonatnih stijena, koje su lokalno proslojene tektonski poremećenim naslagama siltita i pješčenjaka s Fe-Mn konkrecijama. Sam kamenolom nalazi se u zoni dinaridskoga navlačnog pojasa (Pogari serija naslaga) koje diskontinuirano leže na ofiolitnome melanžu i ofiolitnim navlačnim naslagama. Petrografske, kemijske i XRD analize pokazale su da se konkrecije mogu podijeliti u dva tipa: (i) Mn-obogaćene konkrecije s $\approx 17 \mathrm{wt}$.\% udjela Mn s kompaktnom strukturom te (ii) Mn-osiromašene s $\approx 8$ wt. $\%$ udjela Mn te poroznijom strukturom. Udjeli $\mathrm{Ca}, \mathrm{Mg}$, Fe i organske tvari obaju tipova konkrecija podjednaki su. Udio Ni pozitivno korelira s Mn, udio Cr pozitivno korelira s Fe. Prema petrografskim i XRD analizama konkrecije se sastoje od kalcita, dolomita, hematita, todorokita i takanelita. Todorokit je karakterističan mineral za konkrecije formirane dijagenetskim rastom. Petrografska istraživanja potvrdila su rast konkrecija u trima fazama s ukupno dvjema generacijama kalcita. Promatrane konkrecije nalaze se unutar konsolidiranih pješčenjaka te nasljeđuju njihove sedimentne strukture - stoga se pretpostavlja kasnodijagenetski proces rasta.

\section{Ključne riječi:}

Fe-Mn konkrecije, dijagenetski rast, Mn-minerali, kemijske analize, dinaridski ofiolitski pojas

\section{Authors contribution}

Srećko Bevandić (univ.bac.ing.geol.) conducted detailed macro- and micro petrographic analyses, followed by chemical analyses, AAS and XRD analyses, compilation of data, including macro- and micro petrography figures, Tables 1 and 2 (Results), Figure 5 (Discussion), References. Tomislav Brenko (mag.geol.) contributed in Geological setting, preparation of Materials and methods part, compilation of data and XRD interpretation, References, formatting. Elvir Babajić (Assist. Prof.) contributed by initiating an idea on the investigation of the Vijenac Quarry concretions, organising fieldwork, giving a geological background, relevant literature, sampling strategy, as well as the chapter Geological setting. Sibila Borojević Šoštarić (Assoc. Prof.) contributed in field-work, provided investigation strategy, monitored results of the micropetrography, chemical and XRD analyses, guiding preparation of the manuscript, prepared the Abstract, Discussion and Conclusions. 